 \\ a

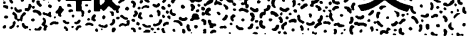 \\ そばの貯蔵及びそば切り加工過程における \\ 収穫後使用農薬の消長 ${ }^{*}$
}

(平成 5 年 4 月 12 日受理)

$\begin{array}{lll}\text { 津村ゆかり*2 } & \text { 長谷川 新*3 } & \text { 関口 幸 } \text { 弘 }^{* 2} \\ \text { 中村優美子 }^{* 2} & \text { 外 海 泰 秀 } & \text { 伊藤誉志男 }\end{array}$

\section{Residues of Post-harvest Application Pesticides in Buckwheat after Storage and Processing into Noodles}

\author{
Yukari Tsumura ${ }^{* 2}$, Shin Hasegawa ${ }^{* 3}$, Yukihiro Sekiguchi ${ }^{* 2}$, Yumiko Nakamura ${ }^{* 2}$, \\ Yasuhide TonOGAI ${ }^{* 2}$ and Yoshio ITO*2 \\ (*2 National Institute of Hygienic Sciences, Osaka Branch: 1-1-43, Hoenzaka, Chuo-ku, \\ Osaka 540, Japan; ${ }^{* 3}$ Kobe Center for Quality Control and Consumer Service: \\ 1-4, Onohama, Chuo-ku, Kobe 651, Japan)
}

The residue levels of 5 pesticides in post-harvest-treated buckwheat during storage and processing into noodles have been investigated. Buckwheat was sprayed with a solution of DDVP, chlorpyrifos-methyl, malathion or fenitrothion, or fumigated with methyl bromide, and stored at $15^{\circ} \mathrm{C}$ followed by determination of pesticide residue levels by FPD- or ECD-GC at intervals of a few days. Based on 84 days' observation, the half lives of the pesticides ranged from 13 days to 124 days. DDVP gave a biphasic semilogarithmic dissipation curve, in which the residue level decreased rapidly in the first phase, and then more slowly in the second phase. On the 3rd or 5th week of storage, buckwheat was processed into noodles and the levels of pesticides were determined after each processing step. In the final product (noodles), $61 \%$ of chlorpyrifos-methyl, $40 \%$ of malathion, $42 \%$ of fenitrothion and $21 \%$ of methyl bromide remained (initial contents taken as 100\%), while no DDVP was detected.

(Received April 12, 1993)

Key words：そば buckwheat；ポストハーベスト使用 post-harvest application；DDVP DDVP； クロルピリホスメチル chlorpyrifos-methyl; マラチオン malathion; フェニトロチオン fenitrothion; 臭化メチル methyl bromide; ガスクロマトグラフィー (ECD, FPD) gas chromatography (ECD, FPD)

著者らは，近年輸入食品の衛生上の注目を集めている 収穫後（ポストハーベスト）使用農薬の残留性について

*1 ポストハーベスト使用される農薬に関する研究（第 5 報）

*2 国立衛生試験所大阪支所： T540 大阪市中央区法円坂 1-143

*3 神戸農林水産消費技術センター：６551 神戸市中央区小野 浜町 1-4
継続して研究を行ってきた.これまでに，ばれいしょ，

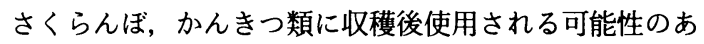
る延べ 16 種の農薬について，保存期間中，またはフレ ンチフライ, デンプン, 砂糖漬け, あるいはマーマレー ドに加工した際の消長実態を明らかにした1〜4). 今回は, そばについて同様の検討を行った。 そばは，我が国にお いては年間 10 万トン以上消費されている重要な穀物で 


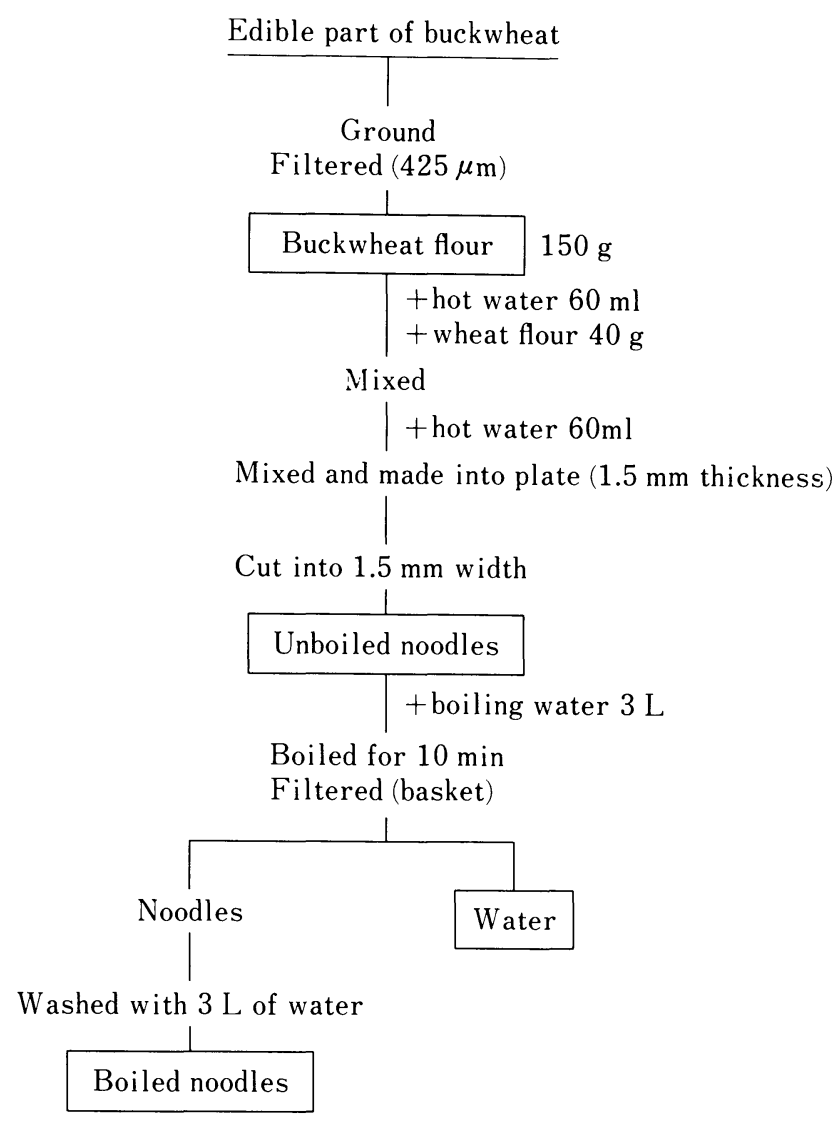

Scheme 1. Manufacturing process to prepare buckwheat noodles

あるが，残留農薬の分析法及び残留実態に関する報告は 極めて少な(い) ${ }^{5)}$.

国内で消費される玄そば（殸つきのそば）の８割以上 は主に中国からの輸入品であり, 防度上の理由から臭化 メチルくん蒸される. そばの残留臭素の基準値は, 全作 物中で最む高い $180 \mathrm{ppm}$ と定められている。 また過去 の実態調查ではそばからマラチオンとフェニトロチオン が検出されている ${ }^{5), 6}$. 臭化メチル, マラチオン, フェニ トロチオンに加えて, 輸入農作物からの検出例が多いク ロルピリホスメチル ${ }^{8), 9)}$ ，そして揮発性の高い農薬の例 として DDVP を今回検討対象として，保存期間中及び そば切り加工過程における消長を検討した，マラチオン

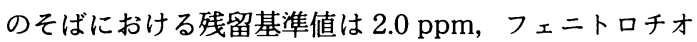
ンは $1.0 \mathrm{ppm}$ であり, DDVP とクロルピリホスメチル については未設定である.

\section{実験方法}

1. 試料

そば（玄そば）は箱館そば生産組合（滋賀県）から入 手した. 1992 年 11 月に収穫されたもので, 農薬の収穫 後処理はなされていない. $4.00 \mathrm{~mm}$ のふるいを通過し
$3.35 \mathrm{~mm}$ のふるいを通過しない粒のみを用いた.

\section{2. 農薬標準品}

DDVP： $98.0 \%$ 以上（和光純薬工業(株)）

クロルピリホスメチル： $99.0 \%$ 以上（和光純薬工業 (株))

マラチオン：98.0\%（和光純薬工業(株)）

フェニトロチオン: $97 \%$ (Riedel-de-Häen)

臭化カリウム：特級（石津製薬(株)）

\section{3. 喷霧用農薬}

DDVP 乳剂：DDVP 50.0\%（武田薬品工業(株)）

レルダン乳剂：クロルピリホスメチル $25.0 \%$ (クミア イ化学工業(株))

マラソン乳剂：マラチオン $50.0 \%$ (三共(株))

スミチオン乳剤：MEP（フェニトロチオン） $50.0 \%$ (三共(株))

\section{4. 装置・器具・試楽}

ECD-GC：(株)柳本製作所 G-2800；FPD-GC：(株)島 津製作所 GC-14A；試薬及び有機溶媒：試薬特級; 水：再 蒸留脱イオン水; 霧吹き：園芸用

コーヒーミル：家庭用, 手回し式；しゃむじ：米飯用, 
Table 1. Recoveries of Pesticides in Buckwheat and Its Product

\begin{tabular}{|c|c|c|c|c|c|}
\hline \multirow[b]{2}{*}{ Compound } & \multicolumn{3}{|c|}{ Recovery $\pm \mathrm{SD}(\%)$} & \multicolumn{2}{|l|}{$(n=3)$} \\
\hline & $\begin{array}{l}\text { Edible } \\
\text { part*1 }\end{array}$ & Hulls*2 & $\begin{array}{l}\text { Unboiled } \\
\text { noodles*1 }\end{array}$ & $\begin{array}{c}\text { Boiled } \\
\text { noodles*1 }^{* 1}\end{array}$ & $\begin{array}{c}\text { Water*3 } \\
\text { after boiling } \\
\text { noodles }\end{array}$ \\
\hline DDVP & $95.8 \pm 1.6$ & $92.8 \pm 6.0$ & $93.2 \pm 2.7$ & $89.3 \pm 0.1$ & $97.2 \pm 3.2$ \\
\hline Chlorpyrifos-methyl & $93.7 \pm 5.3$ & $100.5 \pm 4.6$ & $104.2 \pm 1.2$ & $101.2 \pm 2.7$ & $88.0 \pm 2.0$ \\
\hline Malathion & $96.9 \pm 7.8$ & $97.0 \pm 8.8$ & $99.2 \pm 1.1$ & $97.2 \pm 3.8$ & $99.5 \pm 4.4$ \\
\hline Fenitrothion & $97.9 \pm 6.5$ & $98.8 \pm 10.4$ & $99.8 \pm 1.7$ & $104.4 \pm 8.1$ & $99.0 \pm 2.0$ \\
\hline Methyl bromide & $86.3 \pm 2.4$ & $102.6 \pm 10.7$ & $85.3 \pm 3.5$ & $84.7 \pm 6.5$ & $94.0 \pm 7.2$ \\
\hline
\end{tabular}

Fortification levels were: ${ }^{* 1} 0.2$ ppm for organophosphorus pesticides and 5 ppm for methyl bromide; *2 $1.0 \mathrm{ppm}$ for organophosphorus pesticides and $5 \mathrm{ppm}$ for methyl bromide; *3 $0.04 \mathrm{ppm}$ for organophosphorus pesticides and $5 \mathrm{ppm}$ for methyl bromide.

木製

\section{5. 農薬適用方法}

\section{1 有機リン剂喷霧}

DDVP 乳剂 $1 \mathrm{ml} ，$ レルダン乳剂 $2.4 \mathrm{ml}$ ，マランン乳 剤 $1.6 \mathrm{ml}$, スミチオン乳剂 $3.0 \mathrm{ml}$ をとり, 蒸留水で 100 $\mathrm{ml}$ に定容した．この農薬乳剂混合液を 20 倍希釈し，霧 吹きに入れ，このうち $40 \mathrm{ml}$ をバットに敷き詰めたそば $2 \mathrm{~kg}$ に，しゃもじでかきまぜながら均等に噴霧した。 (噴霧濃度は DDVP $5 \mathrm{ppm}$, クロルピリホスメチル 6 $\mathrm{ppm}$, マラチオン $8 \mathrm{ppm}$, スミチオン $15 \mathrm{ppm})$. 次にバ ットをドラフト内に置き, 扇風機で送風しながら乾燥 後, ダンボール箱に詰め, 冷蔵庫に入れ $15^{\circ}$ で保存した。 噴霧後 0 日より順次適当な期日にサンプリングし, 重量 と各農薬の濃度を測定した。

\section{2 臭化メチルくん蒸}

そば $2,000 \mathrm{~g}$ をダンボール箱に詰め, 臭化メチルくん 蒸した。くん蒸条件は以下のとおりである.

倉庫体積： $929 \mathrm{~m}^{3}$

$\mathrm{CH}_{3} \mathrm{Br}: 16.0 \mathrm{~kg}\left(17.0 \mathrm{~g} / \mathrm{m}^{3}\right)$

〈ん蒸時間：48 時間

〈ん蒸終了時 $\mathrm{CH}_{3} \mathrm{Br}: 10.6 \mathrm{~g} / \mathrm{m}^{3}$

くん蒸直後を 0 日目として順次適当な期日にサンプ リングし, 重量と残留臭素濃度を測定した。

6. 調理加工

(1) 乳鉢を用いてそばの可食部を粉砕し， $425 \mu \mathrm{m}$ の ふるいを通るものを「そば粉」とした.

(2) そば粉 $150 \mathrm{~g}$ をとり, 熱湯 $60 \mathrm{ml}$ を加えてよくこ ね, 小麦粉（強力粉） $40 \mathrm{~g}$ を加えて更によくこねた.

(3) 熱湯約 $60 \mathrm{ml}$ (差し湯) を少しずつ加えて更にこ ね，まな板の上で麺棒等を用いて圧延を繰り返した。

(4) 厚さ約 $1.5 \mathrm{~mm}$ 程度まで圧延した後, 包丁で約 $1.5 \mathrm{~mm}$ 幅に切断し「そば切り（生麺）」とした.

(5) 生麺を熱湯 $3 \mathrm{~L}$ 中で 10 分間ゆでた。

(6) ステンレス製のざるを用いて麺と「ゆで汁」とを
Table 2. Initial Levels of Pesticides in the Buckwheat

\begin{tabular}{|c|c|c|}
\hline \multirow{2}{*}{ Pesticide } & \multicolumn{2}{|c|}{ Concentration $(\mathrm{ppm}) \quad(n=3)$} \\
\hline & Edible part & Hulls \\
\hline DDVP & ND & ND \\
\hline $\begin{array}{l}\text { Chlorpyrifos- } \\
\text { methyl }\end{array}$ & ND & ND \\
\hline Malathion & ND & $\mathrm{ND}$ \\
\hline Fenitrothion & ND & ND \\
\hline $\begin{array}{l}\text { Methyl } \\
\text { bromide*1 }\end{array}$ & $5.5 \pm 1.4$ & $6.7 \pm 0.8$ \\
\hline
\end{tabular}

$\mathrm{ND}<0.005 \mathrm{ppm}$ for DDVP, $0.01 \mathrm{ppm}$ for chlorpyrifos-methyl, $0.05 \mathrm{ppm}$ for malathion and fenitrothion

*1 Naturally included methyl bromide in buckwheat

分離した。

(7) 缅は蒸留水 $3 \mathrm{~L}$ で洗浄し，「そば切り（ゆで缅）」 とした.

以上の工程を Scheme 1 に示した.

\section{7. 分析用試料調製方法}

\section{1 有機リン剂}

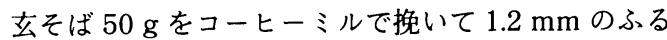
いにかけ，ふるいの目を通過しないものからピンセット を用いて「殼部」を分離した．殼部以外の部分を「可食 部」とした，可食部を $10 \mathrm{~g}$ ，殼部は $2 \mathrm{~g}$ をとり，水 20 $\mathrm{ml}$ で 2 時間以上膨潤した後，既報1に準じて，FPD-GC で 4 種有機りン系農薬の残留量を測定した。調理加工過 程の生麺及びゆで麺については $10 \mathrm{~g}$ ，ゆで汁について は $100 \mathrm{~g}$ を分析に用いた。なお，残留量分析は各試料に ついて 3 試行ずつ行った.

\section{2 臭化メチル}




Table 3. Levels of Pesticides after Application

\begin{tabular}{lccc}
\hline \multirow{2}{*}{ Pesticide } & \multicolumn{3}{c}{ Concentration (ppm) $(n=3)$} \\
\cline { 2 - 4 } & Edible part & Hulls & Total \\
\hline DDVP & $0.561 \pm 0.227$ & $19.1 \pm 1.3$ & 3.67 \\
Chlorpyrifos-methyl & $0.98 \pm 0.28$ & $13.0 \pm 1.7$ & 2.99 \\
Malathion & $0.95 \pm 0.35$ & $20.1 \pm 2.4$ & 4.16 \\
Fenitrothion & $2.13 \pm 0.73$ & $38.8 \pm 4.6$ & 8.27 \\
Methyl bromide & $22.1 \pm 4.0$ & $185.7 \pm 3.6$ & 48.2 \\
\hline
\end{tabular}

Table 4. Half Lives of Post-harvest-Applied Pesticides in Buckwheat Stored at $15^{\circ} \mathrm{C}$

\begin{tabular}{lcr}
\hline \multicolumn{1}{c}{ Pesticide } & Formula & $\begin{array}{c}\text { Half life } \\
\text { (day) }\end{array}$ \\
\hline DDVP*1 (first phase) $_{\text {(second phase) }}$ & $\ln \mathrm{y}=-0.05159 \mathrm{x}+1.012$ & 13 \\
Chlorpyrifos-methyl & $\ln \mathrm{y}=-0.00522 \mathrm{x}-0.719$ & 133 \\
Malathion & $\ln \mathrm{y}=-0.00768 \mathrm{x}+1.116$ & 90 \\
Fenitrothion & $\ln \mathrm{y}=-0.00667 \mathrm{x}+1.480$ & 104 \\
Methyl bromide*2 (first phase) & $\ln \mathrm{y}=-0.00557 \mathrm{x}+2.206$ & 124 \\
& $\ln \mathrm{y}=-0.05001 \mathrm{x}+3.805$ & 14 \\
\hline
\end{tabular}

$\mathrm{x}$ : Storage period (days), $\mathrm{y}$ : Concentration of pesticide (ppm)

*1 The time course curve is given in Fig. 1.

*2 The time course curve is given in Fig. 2.

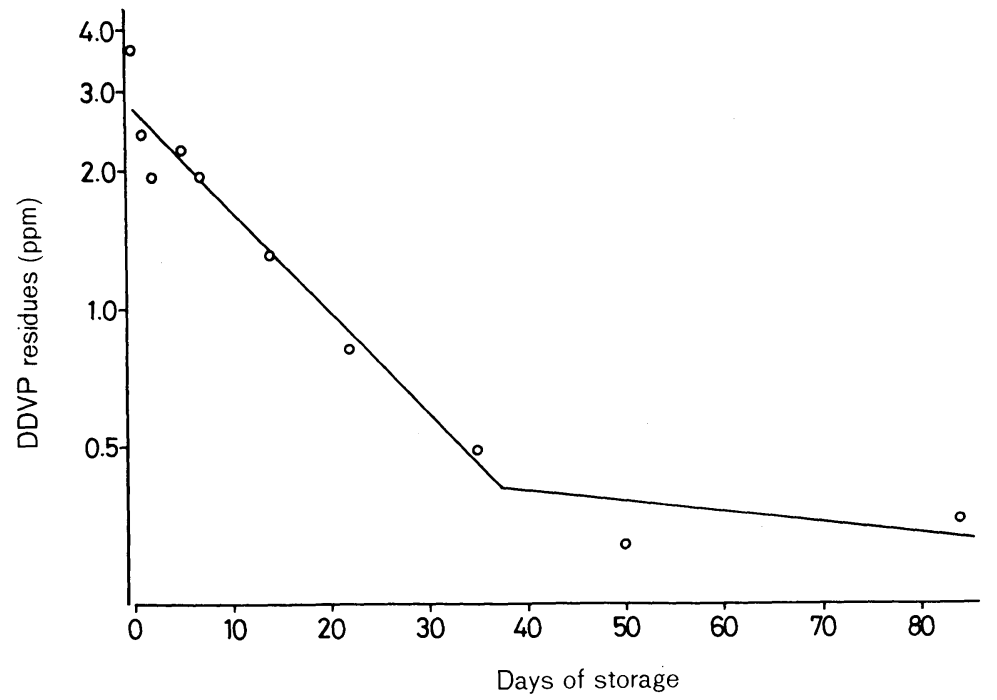

Fig. 1. DDVP residues in post-harvest-treated buckwheat during storage at $15^{\circ} \mathrm{C}$

系農薬の場合と同様に可食部と殼部に分離した，可食部 は $2 \mathrm{~g}$ を，款部は $1 \mathrm{~g}$ を用い，既報 ${ }^{3)}$ に準じて ECD-GC で残留臭素量を測定した。調理加工過程の麺は $2 \mathrm{~g}$,ゆ で汁は $10 \mathrm{~g}$ を分析に用いた. 1 試料について 3 試行を 行った.

\section{結果及び考察}

1. 添加回収率

既報1).31に準じた分析法による，4 種の有機りン系農薬 及び残留臭素のそばまたはそば加工品への添加回収率は 84.7〜104.4\% であった (Table 1).

なお，農薬適用前の玄そば中の農薬も測定したが，臭 素以外は検出されなかった (Table 2)。この臭素は天然 




Fig. 2. Methyl bromide residues in post-harvest-treated buckwheat during storage at $15^{\circ} \mathrm{C}$

Table 5. Ratio of Pesticide Levels Detected in Edible Part of Buckwheat

\begin{tabular}{|c|c|c|}
\hline \multirow[t]{2}{*}{ Pesticide } & \multicolumn{2}{|c|}{$\begin{array}{c}\text { Edible part/whole } \\
\text { buckwheat }(\%)\end{array}$} \\
\hline & 0 day & 84 days \\
\hline DDVP & 12.7 & 8.3 \\
\hline Chlorpyrifos-methyl & 40.7 & 33.6 \\
\hline Malathion & 30.1 & 28.7 \\
\hline Fenitrothion & 33.9 & 30.6 \\
\hline Methyl bromide & 37.6 & 70.1 \\
\hline
\end{tabular}

成分由来と考えられる.

\section{2. 農薬付着量の均一性}

噴霧またはくん蒸直後のそば可食部及び殸部への農薬 付着量を Table 3 に示した. 3 試行の分析の結果, 可食 部の農薬濃度の変動係数が殼部に対して高かったが, こ れは農薬濃度の高い殼の細片が可食部に混入して分析值 に影響を与えたためと思われる。

\section{3. 経時変化}

\section{1 重量変化}

そばの重量は保存中にわずかに増加し，その増加率は 臭化メチルでくん蒸したそばの方が有機リンを噴霧した あのより大きかったが, 最大であ $0.6 \%$ 程度であった. 重量が増加したのは，そばが空気中の水分を吸収したた めと考えられる.

\section{2 濃度変化}

農薬濃度の対数を経過日数に対してプロットしたとこ ろ, 各農薬の減少は直線で近似された。 それらの関数式 及び半減期を Table 4 に示した.
DDVP は最初は速やかに減少し, 続いて緩やかな減少 に転じたため, 38 日付近に変曲点を持つ 2 相直線を与 えた (Fig. 1).これはばれいしょの実験においても観察 された現象であるが4)，最初の速い減少（半減期 13 日） は表面からの農薬の揮発などが, 次の緩やかな減少（半 減期 133 日）は微生物・酵素による分解などが主要因で はないかと考えられる. 一方 DDVP 以外の 3 種の有機 リン系農薬は観察期間中一定の減少率を示し, 単相のグ ラフを与えた.これらは DDVPに比して減少速度が遅 いため, 2 相の前半部分のみが現れて単相となっている 可能性がある.

残留臭素は 10 日間程度は直線的に減少したが，その 後緩やかな増加に転じ, 60 日後頃から一定の值になっ た (Fig. 2). 前半の減少は臭化メチルの揮発によるもの と考えられる. 後半の増加は, 作物組織に臭化メチル又 はその他の揮発性の形で吸着している臭素が徐々に無機 イオンに変化して行くため, 灰化法で残留臭素として検 出されるようになると考えられる. このような増加傾向 は，かんきつ中の残留臭素についても観察されている. 過去にも報告した3).

\section{3 農薬の可食部への移行性}

保存期間中のそばから検出された農薬のうち, 可食部 から検出された比率の变化を Table 5 に示した. 残留臭 素濃度は殼部では 7 日目まで減少したが可食部では増 加した. これは臭化メチルが款部から可食部へ浸透した ためと考えられる. 有機リン系農薬はそば中での浸透, 移行を示さず, 可食部に含まれる割合は変化しなかっ た.

\section{4. 調理加工過程における消長}

農薬を噴霧またはくん蒸した玄そばからそば切りを製 


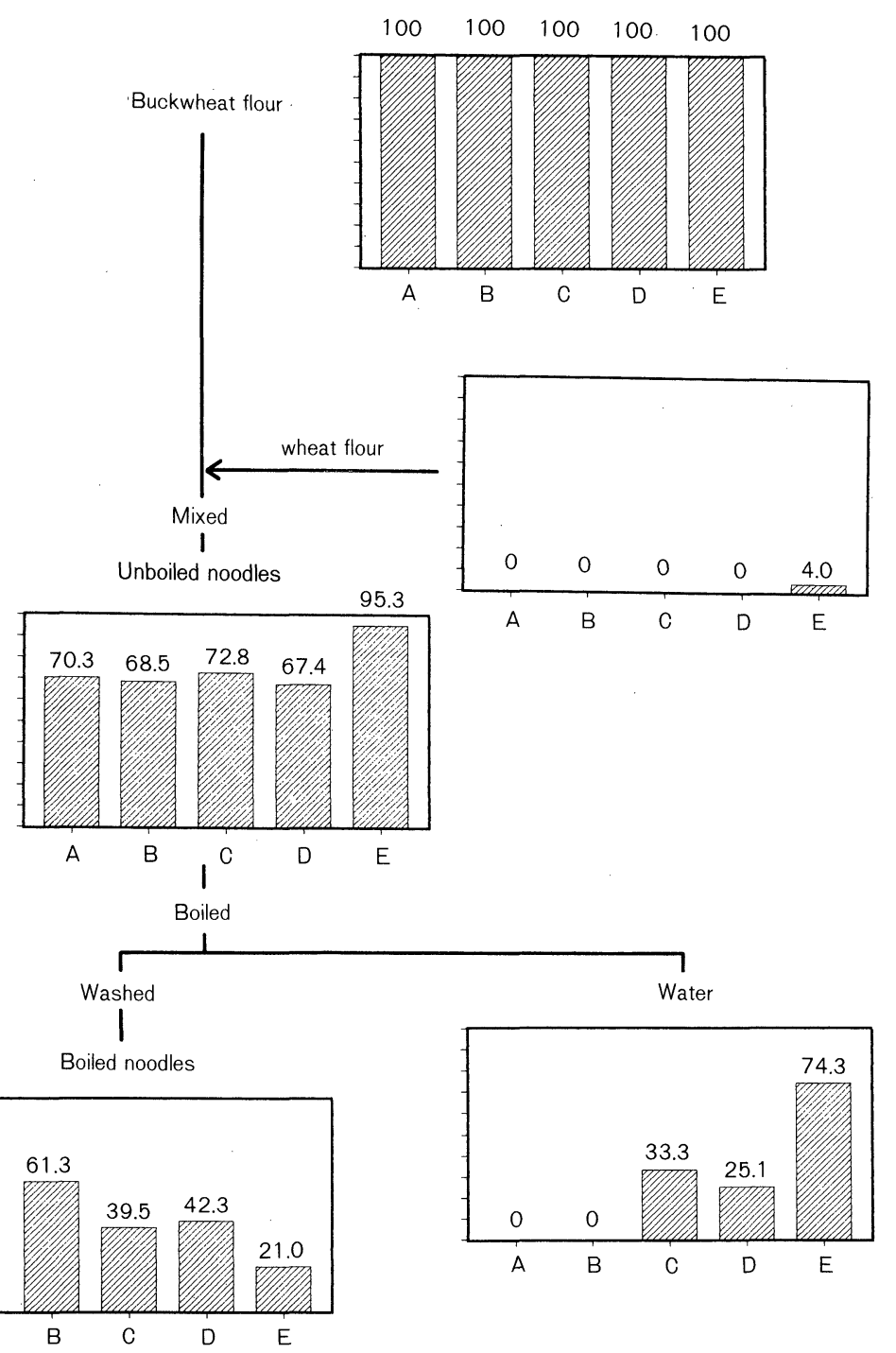

Fig. 3. Residue levels (\%) of the post-harvest-applied pesticides at each step of processing buckwheat into noodles

A: DDVP; B: chlorpyrifos-methyl; C: malathion; D: fenitrothion; E: methyl bromide

造し, 各過程における試料の重量変化を補正して, 農薬 の含有量を測定した，その結果を Fig. 3 に示した。 そば 粉に「うなぎ」として混入した小麦粉からは，有機リン 系農薬は検出されなかったが，4\% 相当の臭素が検出さ れた，玄そば中の農薬はそば切り製造過程において含有 量が減少した. DDVP は最も減少率が大きく, 最終製品 のゆで麺にもゆで汁にも残留は認められなかった。 DDVP は分子量が低く揮発性が高いため, 熱湯で処理す ることによって揮発または分解したと考えられる. クロ ルピリホスメチルは最す残留性が高く，麺中に $61.3 \%$ 残留したが，ゆで汁からは検出されなかった，クロルピ
リホスメチルは分子中に塩素を 3 原子含み脂溶性が高 いためゆで汁中に移行しにくく，麺に残留したものと考 えられる. マラチオンとフェニトロチオンは約 $40 \%$ が 麺に残留し， $30 \%$ がゆで汁に移行した。 臭素は $74.3 \%$ がゆで汁中に移行し，麺には $21.0 \%$ 残留したのみであ った．残留臭素は無機イオンの形で食品に含まれている とされており，水溶性が高いためゆで汁に多く移行した あのと考えられる.

以上のようにそばに収穫後使用された農薬は，水溶性 の高い物質はゆで汁に, 脂溶性の高い物質はゆで缅に残 留する傾向があった。 
仮に残留基準値と同じ濃度の農薬を含む玄そば $100 \mathrm{~g}$ を用いて，そば切りを製造したとすると，そば粉は約 83 $\mathrm{g}$, ゆでめんは約 $173 \mathrm{~g}$ 得られる. このゆでめんに含ま れる農薬の量はマラチオン $22.7 \mu \mathrm{g}$, フェニトロチオン $12.9 \mu \mathrm{g}$, 臭素 $2.65 \mathrm{mg}$ であり, 摂取者の体重を $50 \mathrm{~kg}$ とすれば，それぞれ 1 日摂取許容量 (ADI) の 2.3，5.2, $5.3 \%$ に当たる. また, ゆで汁を全部飲んだ場合は, 最も 残留率の高い臭素の摂取量でも ADI の $18.7 \%$ であり, 健康上の問題はないと考えられる.

\section{謝辞}

そばのくん蒸にご協力頂いた大阪燻蒸(株)に深謝しま す.

\section{文献}

1）長谷川ゆかり, 外海泰秀, 中村優美子, 伊藤誉志男: 食衛 誌. 32, 128〜136 (1991).

2) 長谷川ゆかり, 外海泰秀, 中村優美子, 伊藤誉志男: 同上
32, 427〜433 (1991).

3) 津村 (長谷川) ゆかり, 外海泰秀, 中村優美子, 伊藤誉志 男: 同上 33, 258 266 (1992).

4) Tsumura-Hasegawa,Y., Tonogai, Y., Nakamura, Y., Ito, Y.: J. Agric. Food Chem. 40, 1,240 1,244 (1992).

5）吉田精作, 村时 弘, 今井田雅示: 大阪府立公衛研所報 食品衛生編 22, 59 68 (1991).

6) 小西良昌, 吉田精作, 今井田雅示：同上 18, 63 68 (1987).

7) Aoki, Y., Takeda, M., Uchiyama, M.: J. Assoc. Off. Anal. Chem. 58, 1,286 1,293 (1975).

8）永山敏廣, 真木俊夫, 観 公子, 飯田真美, 川合由華, 二 島太一郎：食衛誌. 30, 438 443 (1989).

9) Tonogai, Y., Tsumura, Y., Nakamura, Y., Ito, Y., Watanabe, Y., Shiomi, Y.: Bull. Natl. Inst. Hygien. Sci. 110, $140 \sim 143$ (1992). 